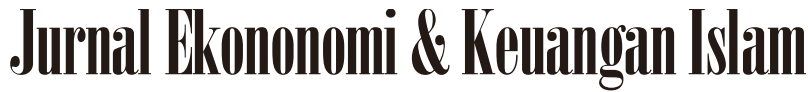

\author{
Available at http://journal.uii.ac.id/index.php/jeki
}

\section{The analysis of relationship between return rate on deposit of Islamic bank and conventional bank in Indonesia}

\author{
Suyyinah", Akhsym Affandi \\ Department of Economics, Islamic University of Indonesia, Yogyakarta, Indonesia \\ *Corresponding author: suyyinah0896@gmail.com
}

\section{Keywords:}

PLS Rate, Interest Rate, Deposit, Conventional Bank, Islamic bank

DOI:

$\underline{\text { 10.20885/JEKI.vol4.iss1.art3 }}$

\begin{abstract}
This research analyzes the correlation of conventional and Islamic bank deposit return in Indonesia, using monthly data from February 2009 to February 2014. The method analysis shows that there is long-run relationship between conventional and Islamic bank deposit return. Shock of conventional deposit rate influence the fluctuation of Islamic deposit return and vice versa. Shock of Islamic deposit return has less contribution to explain the fluctuation of conventional deposit rate in all deposit model (1-month deposit, 3-month deposit, 6-month deposit, and 12-month deposit) than shock of conventional deposit rate explain the fluctuation of Islamic deposit return. It happens because market share of conventional banking is larger than Islamic banking. Therefore, if there is shock in Islamic deposit return, it does not influence much to explain the fluctuation of conventional deposit rate.
\end{abstract}

\begin{abstract}
Abstrak
Penelitian ini menganalisis hubungan antara tingkat bagi hasil deposito bank syariah dengan tingkat suku bunga deposito bank konvensional yang ada di Indonesia menggunakan data bulanan periode Februari 2009 hingga Februari 2014. Metode yang digunakan adalah metode VECM. Hasil analisis menunjukkan bahwa terdapat hubungan jangka panjang antara tingkat bagi hasil deposito bank syariah dengan tingkat suku bunga bank konvensional pada semua model deposito berjangka (deposito 1 bulan, deposito 3 bulan, deposito 6 bulan, dan deposito 12 bulan) dalam penelitian. Hasil olah data menunjukkan bahwa peranan guncangan tingkat suku bunga deposito bank konvensional dalam menjelaskan fluktuasi tingkat bagi hasil deposito bank syariah lebih besar dibandingkan peranan guncangan tingkat bagi hasil deposito bank syariah dalam menjelaskan fluktuasi tingkat suku bunga deposito bank konvensional.
\end{abstract}

\section{Background}

According to Law of Republic of Indonesia No.7 Year 1997 bank is a business entity that collects funds from the community in the form of savings and channeled to the community in order to improve the standard of living of many people. (Perwataatmajaya \& Tanjung, 2007). As a financial institution, the Bank in its daily life can not be separated from the financial field. This activity is usually known by collecting funds from the community and channeling public funds with the goal of providing benefit for the ummah. (Rivai \& Arifin, 2010; Hakim, 2011). Indonesia is one of the countries that implement dual banking system that is conventional and Islamic system where in general two systems have the same goal that is collecting and channeling funds to the community which become the difference of both is the operational system and the concept applied, conventional banking apply interest rates while Islamic banks apply profit sharing. (Antonio, 2001, Latiff \& Halid, 2012).). In 1997 Southeast Asia experienced a monetary crisis that could change the Indonesian economy became worse. The monetary crisis is affecting the companies that exist in the country, especially in the banking sector. The banking sector is highly dependent on the position of the exchange rate because their transactions use foreign currency. Monetary crisis also worsened the national economy. (Sudarsono,2009; Anwar, \& Watanabe. 2010).

However, in Indonesia Islamic banking System is still lack of public recognition, it can be proven by the assumption from the public that Islamic banking is the same as conventional banking using interest rate system. (Beck, et al, 2010). The development of Islamic banking in Indonesia may still be affected by the existence of existing conventional banking system. Indonesian banks are still referring to BI rate. BI rate or commonly referred to interest rate of Bank Indonesia is the benchmark interest rate or policy interest rate set by Bank Indonesia as an institution of monetary policy authority in Indonesia. 


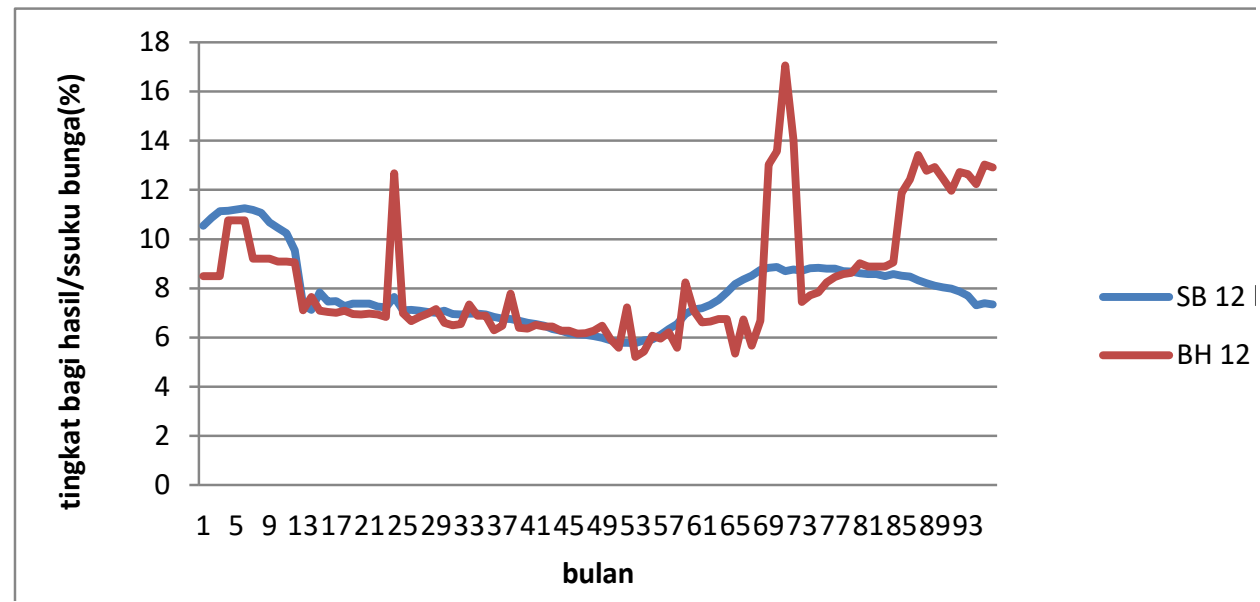

Picture 1. The Rate of Profit-Loss Sharing and Interest on 12-Month Deposit

The picture shows that in the period January 2009 to December 2016 changes in profit sharing in Islamic banking is still following the change in interest rates. This proves that the market share of Islamic banking has not been as wide as conventional banking, so to expand its market share of Islamic bank tends to refer to conventional bank interest rate in determination of profit margin.

According to the classical theory interest is a reward or compensation paid by the borrower to the lender. According to LPPI (1980), interest is the benefit of using a certain amount of money under a loan and lending agreement. According to Indonesian banking, the interest rate is the compensation paid by the borrower on the received fund, the interest expressed in percent, usually interest in form of return and has been determined unilaterally by the creditor in every time unit (daily, weekly, monthly and yearly) from the utilization of a number of "cash withdrawals" or withdrawals of funds from a lending and borrowing transaction, for example $1 \%$ per month or $12 \%$ per annum of principal. (Arif, 2010)

Profit/Loss Sharing Rate (PLS rate) is a profit-sharing principle established with partners, where the percentage of profit sharing is determined at the time of agreeing akad. If a business gets a profit, then the profit sharing is done according to the agreement. On the other condition, PLS loss is adjusted to the capital contribution of each party (Ascarya, 2006). Revenue sharing is profit sharing system where capital owner cooperates with capital manager to conduct business activity (Muhammad, 2005; Chong \& Liu, 2009; Natalia, et al, 2014 ).

According to the study conducted by Isna and Kunti (2012), ROA, BOPO, and interest rate has an impact toward PLS rate on mudharabah deposit of Islamic banks. Additionally, Pramilu (2012) found that ROA, BOPO, and CAR has a negative effect toward PLS rate on mudharabah deposit of Islamic banks, while ROE and FRD has no effect toward it. On the other hand, Azmi (2008) revealed that CAR has a significant effect toward PLS rate on mudharabah deposit but FDR has no effect.

Interest rate still becomes a consideration for management of Islamic bank in maintaining bank's liquidity. The increase on interest rate tends to lower the collection of funds in Islamic bank. On the other side, the increase of interest rate will upgrade the ability of Islamic bank to distribute their fund. The effect of interest rate in conventional bank toward PLS rate of mudharabah deposit can be found in the research of Rosyid (2014), Isna and Kunti (2012), Arif (2010), and Azmi (2008). While in the study of Hidayat and Azhari (2015), we can find the causal effect between interest rate and PLS rate in Islamic banks.

Latif and Halid (2012) foun that in the first period there is a cointegration relationship between deposit rate of conventional and Islamic banks. This research is also in line with Cevik and Charap (2011) which found that in a long-term, deposit rate of conventional bank will closely affect PLS rate of Islamic banks in Malaysia and Turkey. While in a long-term, the fluctuations of deposit rate in conventional bank will have a greater impact toward the fluctuations of PLS rate of deposit in Islamic bank, compared to the impact of PLS rate of deposit in Islamic bank toward fluctuation of deposit rate in conventional bank.

\section{Research Method}

Dependent variable is variable that is influenced by or become the result of independent variable, in this research dependent variable used is percentage of profit sharing where profit sharing is system of share of business income where capital owner cooperates with another capital owner to run a business. If the business activity 
generates profit then it will be share together and when suffered losses it will also be borne together. The profitsharing system ensures justice and no party is exploited (Ascarya, 2006).

Independent variable is the variable that influences or causes the change or the emergence of the dependent variable. In this study independent variable is the interest rate in which the interest rate is the remuneration provided by the bank based on conventional principles to customers who buy / sell their products. Interest can also be interpreted as the price to be paid to customers (who have deposits) with what must be paid by customers to the bank (customers who get loans). While the interest rate is the ratio of interest to the total of loan (Karim, 2009).

\section{Data Analysis Technique}

This research uses vector error correction model (VECM) analysis to find out the long-term and short-term relationship dependent variable profit-sharing ratio and independent variable deposit interest. As well as find out impulse response to see the shock of the dependent variable profit-sharing ratio and the independent variable interest rate. Therefore, it can show the length of the shock caused by the variable. (Juanda \& Junaidi, 2012; Widarjono, 2013).

Methods and models in this study refer to research conducted by Cevik and Charap (2011) under the title "The Behavioral of Conventional and Islamic Bank Deposit Return in Malaysia and Turkey".

The VECM equation model in matrix form is:

$\mathrm{Y}_{\mathrm{t}}=\beta_{0}+\beta_{1} \mathrm{Y}_{\mathrm{t}-1}+\beta_{2} \mathrm{Y}_{\mathrm{t}-2}+\beta_{1} \mathrm{X}_{\mathrm{t}-1}+\beta_{2} \mathrm{X}_{\mathrm{t}-2}+\varepsilon_{\mathrm{t}}$

$X_{t}=a_{0}+a_{1} X_{t-1}+a_{2} X_{t-2}+a \beta_{1} Y_{t-1}+a_{2} Y_{t-2}+\varepsilon_{t}$

Where, $\mathrm{Y}$ is PLS rate on 1-Month Deposit of Islamic bank. $\mathrm{X}$ is interest rate on 1-Month Deposit of Conventional Bank. And, a0 and $\beta 0$ : intercept; ct: error term; $\beta 1$ and $\beta 2$ : constant

Table 1. Result of Granger Causality Tests 1-Month Deposit

\begin{tabular}{lccc}
\hline Null Hypothesis: & Obs & F-Statistic & Prob. \\
\hline SB1 does not Granger Cause BH1 & 93 & 4.20690 & 0.0079 \\
BH1 does not Granger Cause SB1 & & 3.62026 & 0.0163 \\
\hline
\end{tabular}

Source: Data processed

Granger causality test is used to find the causal relationship that occurs among the variables within the model in the study period. The result of granger causality test for 1-month deposit and 1-month deposit with 3 lags can be informed that interest rate on deposit of conventional bank is more dominant with PLS rate on deposit of Islamic bank.

Table 2. Result of Granger Causality Tests 3-Month Deposit

\begin{tabular}{lccc}
\hline Null Hypothesis: & Obs & F-Statistic & Prob. \\
\hline SB3 does not Granger Cause BH3 & 93 & 6.61432 & 0.0004 \\
BH3 does not Granger Cause SB3 & & 9.42065 & $2 . E-05$ \\
\hline
\end{tabular}

Source: Data processed

The result of granger causality test of 3-month deposit interest rate and 3-month deposit PLS rate can be informed that on 3-lag PLS rate affects the deposit interest rate at $a=1 \%$ the interest rate also affects the profit share at $a=1 \%$. Therefore, it can be concluded a two-way causality between the three-month deposit and the three-month deposit rate. The interest rate gives a positive influence which means that when there is an increase in the interest rate, it will also increase PLS rate. This happens because of the competition between banks, thus it will be able to maintain their customers which will lead banks to equate the rate of profit margins which will be distributed to customers and other banks.

Table 3. Result of Granger Causality Tests 6-Month Deposit

\begin{tabular}{lccc}
\hline Null Hypothesis: & Obs & F-Statistic & Prob. \\
\hline SB6 does not Granger Cause BH6 & 93 & 5.88825 & 0.0011 \\
BH6 does not Granger Cause SB6 & & 16.0787 & 2. E-08 \\
\hline
\end{tabular}

Source: Data processed 
Granger causality model test results for 6-month deposits and 6-month deposit rates with three lags can be picked up informed that at the three debt-sharing intervenes inaction 3-month affect the 6-month deposit interest rate at $\mathrm{a}=1 \%$ interest rate also affect the PLS rate on deposit at $\mathrm{a}=1 \%$. Therefore, it can be concluded a twoway causality between the 6-month PLS rate and the 6-month deposit rate occurs in all inaction. The interest rate gives a positive influence which means that when there is an increase in the interest rate it will also increase the profit share. This happens because of the competition between banks, thus it is able to maintain their customers which will lead banks to equate the rate of profit margins that will be distributed to customers and other banks.

Table 4. Result of Granger Causality Tests 12-Month Deposit

\begin{tabular}{lccc}
\hline Null Hypothesis: & Obs & F-Statistic & Prob. \\
\hline SB12 does not Granger Cause BH12 & 93 & 1.05271 & 0.3736 \\
BH12 does not Granger Cause SB12 & & 0.56258 & 0.6412 \\
\hline
\end{tabular}

Source: Data processed

The results of the granger causality model test for the 12-month deposit and the 6-month deposit interest rate with the three inaction can be obtained that the 12-month deposit interest rate does not affect the 12-month deposit interest rate as well as the deposit proceeds. Therefore, it can be concluded there is no two-way relationship between the 12-month deposit PLS rate and the 12-month deposit interest rate on all inaction.

\section{VECM Test}

The results of cointegration test show that Islamic bank 1-month long-term deposits have t-statistics of 3.84848> t table $1.960(\alpha=5 \%)$ where the probability of a 1-month deposit is greater than $\alpha=5 \%(0.05)$ ie 14.9235 hence the share of $\mathrm{HO}$ exposure deposit and receive Ha, meaning that the 1-month deposit rate has positive and insignificant effect on the 1-month deposit rate. While the Islamic bank's 3-month deposit showed that in longterm it has a t-statistic of 5.33053> T table of $1.960(\alpha=5 \%)$ and the probability of a 1-month deposit is greater than $\alpha=5 \%$ (0.05) ie 0.13968 hence the proceeds of deposits reject H0 and receive Ha. It means that the 1month deposit return has positive and insignificant effect on the 3-month deposit rate.

Table 5. The Result of Long-Term Analysis VECM Test

\begin{tabular}{cccc}
\hline Period & Standard Error & T_Statistics & Coefficient \\
\hline 1-Month PLS rate & 10,03 & $-3,848$ & $-38,63$ \\
3-Month PLS rate & 0,13968 & $-5,330$ & $-0,7445$ \\
6-Month PLS rate & 0,20855 & $-5,38604$ & $-1,123$ \\
12-Month PLS rate & 0,496 & $-3,0279$ & $-1,5019$ \\
\hline
\end{tabular}

Source: Data processed

The share of the six-month Islamic banking deposit indicates that in long-term it has t-statistics of 5.386> T table of $1.960(\alpha=5 \%)$ and the probability of a 1-month deposit is greater than $\alpha=5 \%(0.05) 0.20855$ then the share of deposits reject $\mathrm{H} 0$ and receive Ha. meaning that the return on 1-month deposits has a positive and insignificant effect on the 6-month deposit rate.

Profit sharing of 12-month Islamic banking shows that in long-term it has t-statistics equal to 3,027> T table equal to $1,960(\alpha=5 \%)$ and the probability of profit sharing one month is greater than $\alpha=5 \%(0,05) 0.05$ then the deposit share receives $\mathrm{H} 0$ and reject Ha. meaning that the return on 1-month deposits has a positive and insignificant effect on the deposit interest rate of 12-month.

Table 2. The Result of Short-Term Analysis VECM Test

\begin{tabular}{ccc}
\hline Period & T_Statistik & Coefficient \\
\hline 1-Month PLS Rate & $-3,566662$ & $-0,200389$ \\
3-Month PLS Rate & 0,87809 & 0,109513 \\
6-Month PLS Rate & 0,13434 & 0,017484 \\
12-Month PLS Rate & $-0,196554$ & -0.022460 \\
\hline
\end{tabular}

Source: Data processed

From the results of the research shown in the table above the relationship between PLS and interest rate on deposit can be seen from the statistical $t$ value of the major coefficients in each period either a period of 1 -month, 
3-month, 6-month and 12-month which means that in the first lag PLS rate positively and significantly influence deposit interest rate.

\section{Result of Impulse Analysis - Response}

\section{1-Month Deposit}

In the 1-month deposit model in the figure, the effect of 1-month deposit rate shocks on Islamic banks responds to 1-month deposit rates in conventional banks is still fluctuating, meaning that the 1-month deposits of Islamic banks responded shock on the deposit rate of one month conventional bank from year to one until the second year increases and becomes stable in year three to ten.

Response to Cholesky One S.D. Innovations \pm 2 S.E.

Response ofBH_1_BULAN to BH_1_BULAN

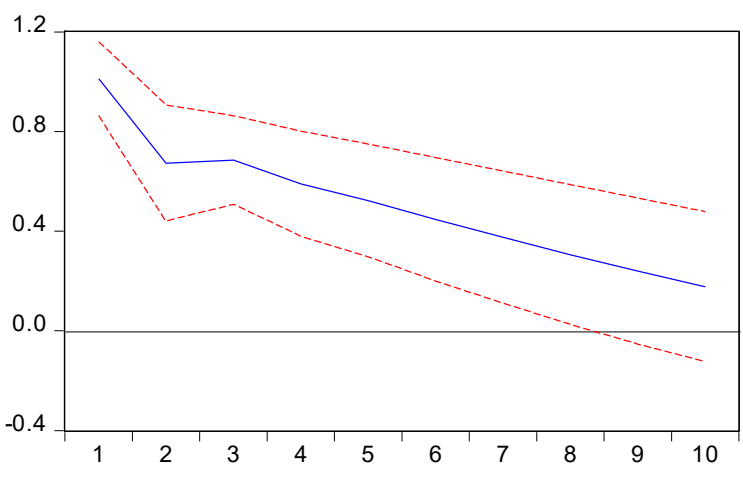

Response of SB_1BLN to BH_1_BULAN

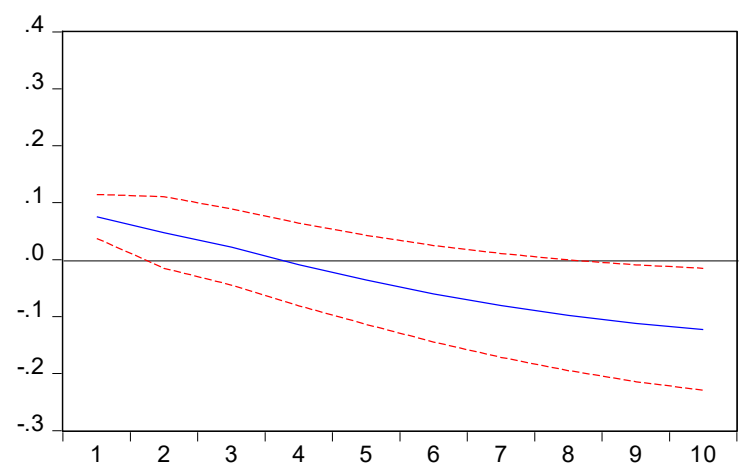

Response ofBH_1_BULAN to SB_1BLN

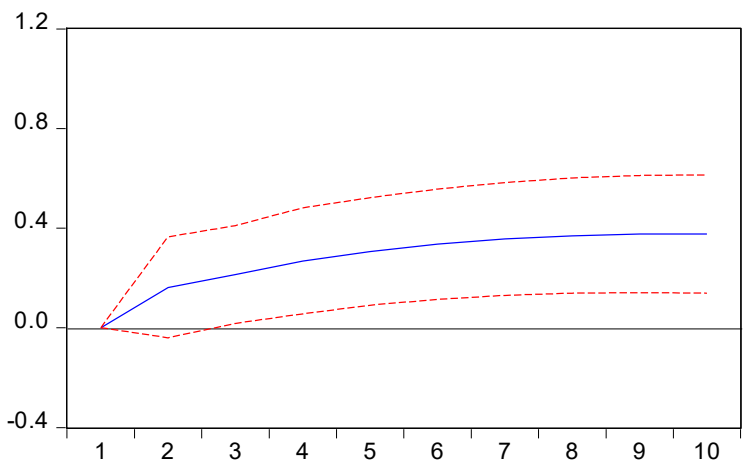

Response of SB_1BLN to SB_1BLN

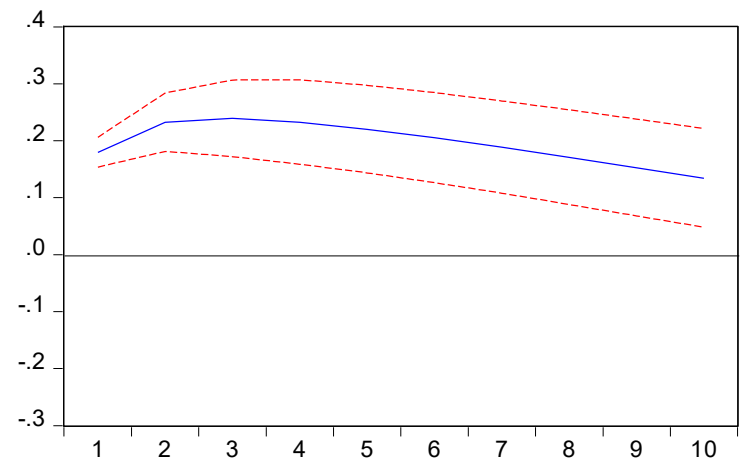

Picture 2. The Result of IRF Test, data processed

The IRF result on the 1-month deposit model shows that the conventional bank deposit rate response on the shocks occurring at the PLS rate on deposit of Islamic bank shows a smaller degree than the Islamic bank's PLS rate response to shocks that occur at the interest rate conventional bank deposits. The 1-month PLS response to the positive surprise of the interest rate is positive and significant while the 1-month deposit rate response to the negative surprise of profit sharing is negatively insignificant. This is because the market share of conventional banks in Indonesia is still larger than the Islamic banks.

\section{3-Month Deposit}

In the 3-month deposit model, the shock of the 3bulan deposit rate of Islamic bank responds to the 3-month deposit rate of the conventional bank deposit rate. This means that the 3-month deposits of Islamic banks shook shocks at 3-month deposit rates of conventional banks from 1 to 3 years decreased and subsequently remained constant in the following year and increased in the 4th to 10th year. on the other hand, interest rate, 3-month deposit interest rate give response to profit sharing of 3-month in Islamic bank. 
Response to Cholesky One S.D. Innovations \pm 2 S.E.

Response of BH_3_BULAN to BH_3_BULAN

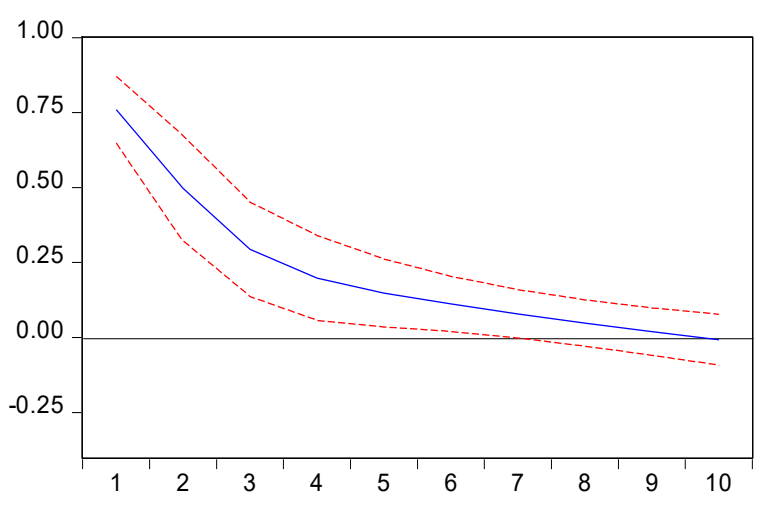

Response ofSB_3_BULAN to BH_3_BULAN

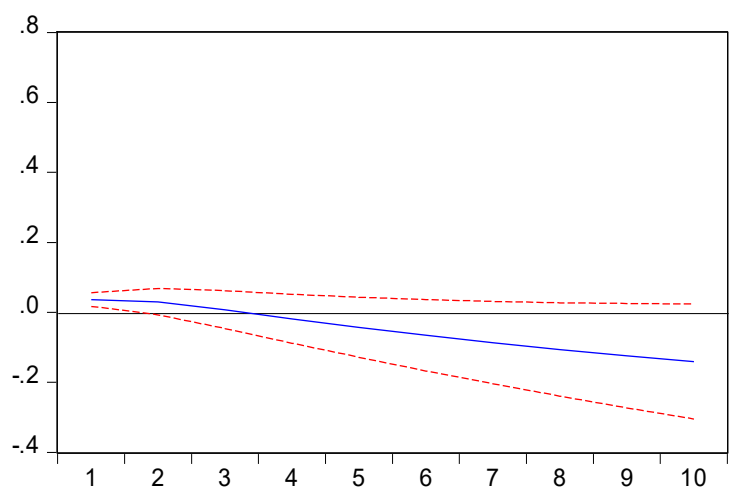

Response ofBH_3_BULAN to SB_3_BULAN

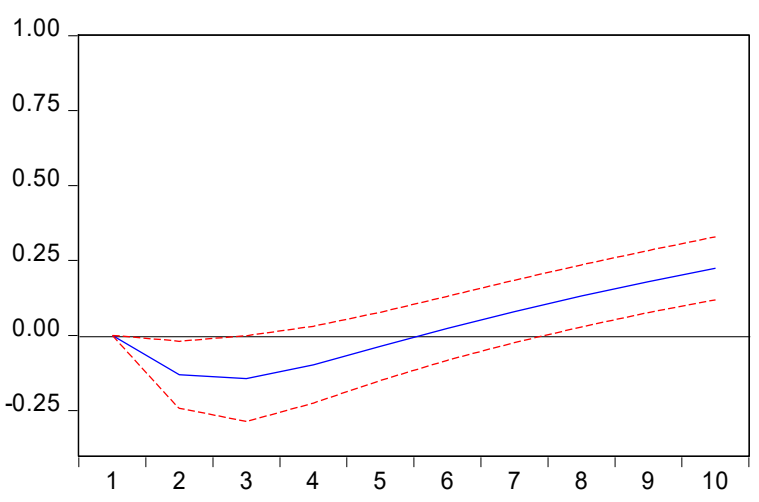

Response of SB_3_BULAN to SB_3_BULAN

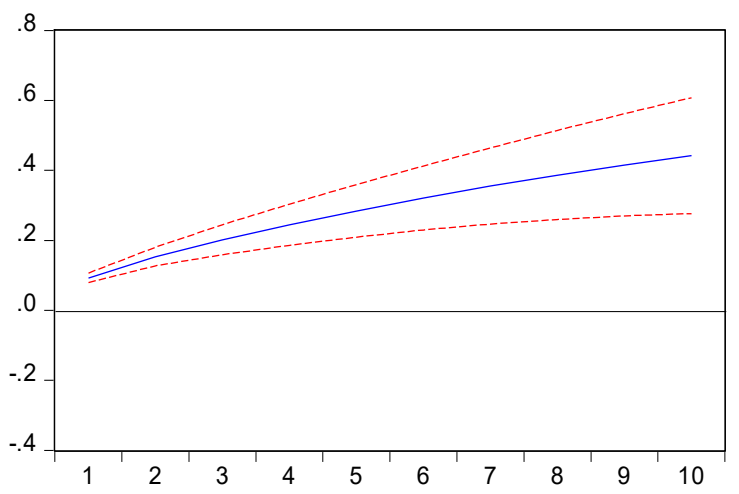

Picture 3. The Result of IRF Test, data processed

The PLS response of the three-month deposit caused by the surprise of the interest rate is negative and significant against the 1-month deposit rate. The interest rate response to the revenue share does not give a negative and significant shock. The IRF yields a three-month deposit model, which indicates that the Islamic bank deposit rate in Indonesia response to conventional bank deposit rate shocks shows a greater degree than conventional bank deposit rate response to PLS rate on deposit of Islamic bank. Similarly, in Malaysia and Turkey that the Islamic bank's PLS rate responded more favorably to conventional bank rate shocks than conventional bank interest rate responses to shocks that occurred at the sharecropping rate of Cevik and Charap (2011).

\section{6-Month Deposit}

The response of 6-month PLS rate to positive shocks caused interest rates to be positive and significant. While the shocks that the resulting profit sharing on the interest rate is negative and significant. In the 6-month deposit model, the surprise rate of 6-month deposits of Islamic banks responded to the 6-month deposit rate on conventional bank deposit rates. This means that the Islamic bank's 6-month deposit share deposit responds to shocks on the conventional bank's 6-month deposit rate from year 1 to year 2 and decreases subsequently the next year declines and increases again in the 4th to 10th year. on the contrary, interest rate, 6-month deposit interest rate give response to 6-month deposit share in Graph of IRF test result. Perwataatmaja and Tanjung (2007) say that in order to win the competition to attract investors, often Islamic financial institution in Indonesia equate the results to be provided to investors with the interest rate deposits provided conventional bank to its customers. This is why the response rate of Islamic bank deposits to shocks that occurred at conventional bank deposit rates in Indonesia is smaller. 
Response to Cholesky One S.D. Innovations \pm 2 S.E.
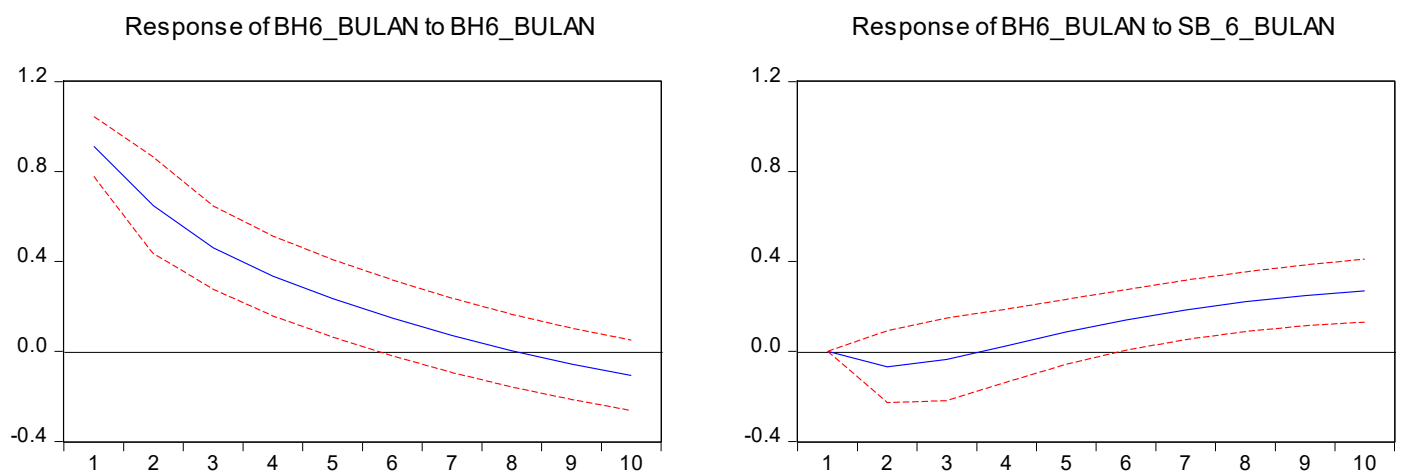

Response of SB_6_BULAN to BH6_BULAN

Response of SB_6_BULAN to SB_6_BULAN
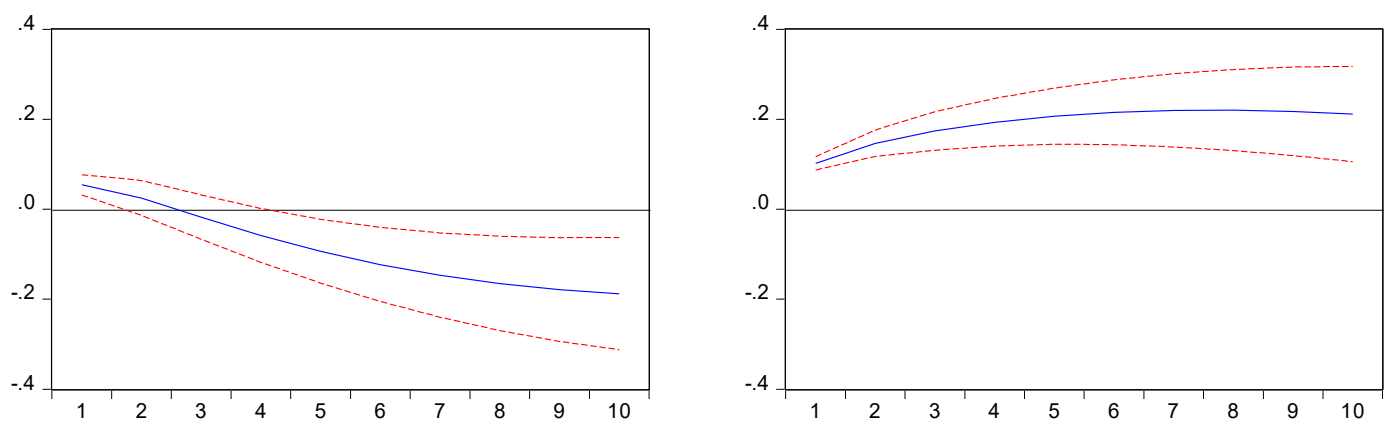

Picture 4. PLS and Interest Rate on 12-Month Deposit

\section{2-Month Deposit}

In the 12-month deposit model, the sharecropping rate shock rate of 12-month of Islamic bank responds to the 12-month deposit rate on conventional bank deposit rates. This means that the 12-month deposits of Islamic banks shook shocks on conventional 12-month deposit rates from year 1 to year 2 have increased and constant for the next year to year 10. Similarly, interest rates, deposit rates 12-month did not give a significant response to the share of 12-month deposit in Islamic bank.

Response to Cholesky One S.D. Innovations \pm 2 S.E.

Response ofBH_12_BULAN to BH_12_BULAN

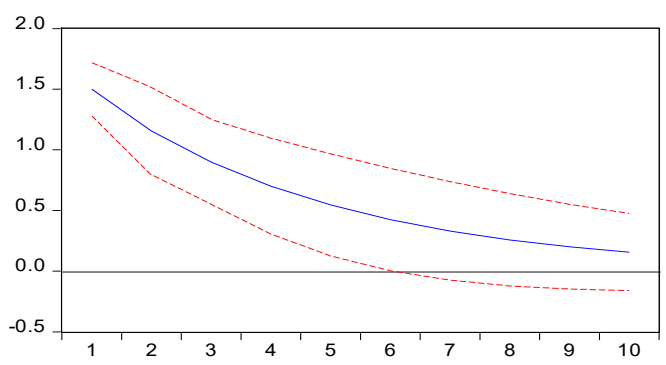

Response of SB_12_BULAN to BH_12_BULAN

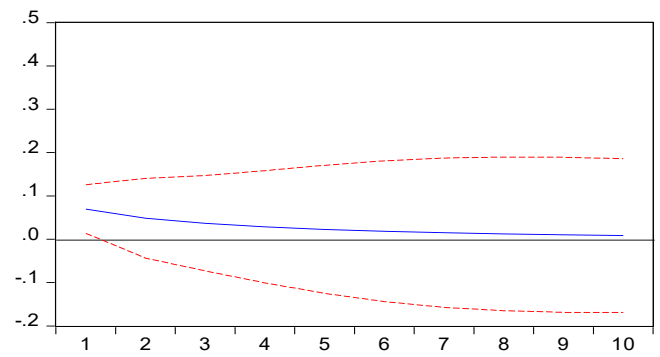

Response of BH_12_BULAN to SB_12_BULAN

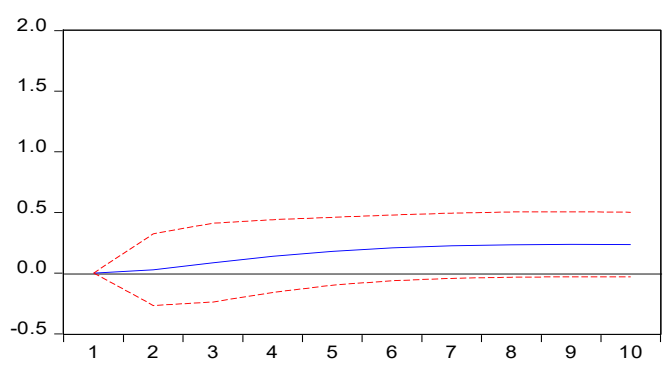

Response of SB_12_BULAN to SB_12_BULAN

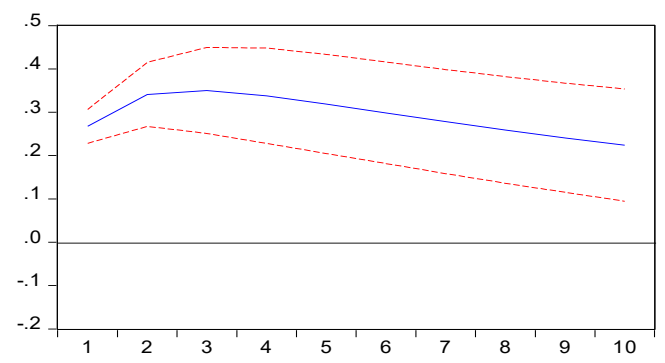

Picture 5. The Result of IRF test, data processed 
The 12-month PLS rate's response to positive interest rate shocks is positive and insignificant. While the shocks resulted from PLS rate toward interest rates are positive and insignificant. Similar to result of 1-month, 3-month, and 6-month deposits, 12-month deposit is also in line with research conducted by Cevik and Charap (2011) that the Islamic bank's PLS rate gives greater response to conventional bank rate shocks than response given the conventional bank interest rate on shocks that occurred at PLS rate of Islamic banks. Arif (2010) in his research conducted in Indonesia, found that in the determination of margin for the results of Islamic banks are still getting influence from conventional bank interest rates. It can be seen that the conventional bank deposit interest rate gives a bigger response.

\section{Conclusion}

In this study, we found that there is a long-term relationship between interest rate of deposit in conventional bank and PLS rate of deposit in Islamic bank. the response of PLS rate of deposit in Islamic bank toward the fluctuation of interest rate of deposit in conventional bank shows a bigger change than vice versa. The response tends to be positive as the interest rate of deposit increases, there will be more Islamic bank's customers shift to conventional bank. For this reason, to keep their customer loyal to the bank, Islamic banks will increase their PLS rate on deposit, and vice versa.

In explaining the fluctuations of interest rate of deposit on conventional bank, the role of PLS rate is still very low in all periodic deposit. This is due to a higher market share of conventional bank compared to the Islamic one. When there is a fluctuation of PLS rate on Islamic bank, it will not significantly affect the fluctuation of interest rate of deposit on conventional bank. On the other hand, the effect of interest rate of deposit on conventional bank toward the fluctuation of PLS rate of deposit on Islamic banks is increasing in a long-term.

Based on this research, there are several suggestions made which are PLS rate on Islamic bank should not depend anymore on interest rate of conventional bank, it should be decided based on the profit of Islamic bank and adjusted to the market condition and purchasing power of society. In addition to that, the future research is suggested to conduct a more comprehensive study about PLS rate and interest rate by adding more variables such as interest and PLS rate of financing because bank's profit is acquired from the interest and PLS rate of bank's financing to the customer.

\section{References}

Antonio, M.S. (2001). Bank Syariah: dari Teori ke Praktek. Jakarta: Gema Insani Press.

Anwar, S. \& Watanabe. K. (2010). Predicting Future Depositor's Rate of Return Applying Neural Network: A Case-Study of Indonesian Islamic Bank, International Journal of Economics and Finance. 2(3), 170176

Arif, M.N.R. (2010). Tingkat Suku Bunga Bank Konvensional dan Pengaruhnya terhadap Penetapan Persentase Bagi Hasil di Bank Syariah. Jurnal Dialog Balitbang Kemenag RI. 69(33), 80 -93

Ascarya (2006). Akad dan Produk Bank Syariah: Konsep dan Praktek di Beberapa Negara. Jakarta: Bank Indonesia

Beck, T., Kunt, A.D \& Merrouche, O. (2010). Islamic vs. Conventional Banking: Business Model, Efficiency and Stability.Journal of Banking \& Finance, 37, 433-447

Cevik, S. \& Charap, J. (2011). The Behavior of Conventional and Islamic Bank Deposit Returns in Malaysia and Turkey. IMF Working Paper. No. WP/11/156

Chong B \& Liu M.H. (2009). Islamic Banking: Interest-Free or Interest Based? Pasific- Basin Finance Journal. $17(1), 125-144$

Hakim, A.A. (2011). Fiqih Perbankan Syariah Transformasi Fiqih Muamalah ke dalam Peraturan PerundangUndangan. Bandung: PT. Refika Aditama

Juanda, B. \& Junaidi. J (2012). Ekonometrika Deret Waktu: Teori dan Aplikasinya. Bogor: IPB Press.

Karim, A. (2009). Bank Islam: Analisis Fiqh dan Keuangan. Jakarta: Rajawali Pers.

Latiff, R.A \& Halid, N. (2012). The Mudharabah Deposit Rate Behaviour in Relation to the Conventional Deposit Rate.Jurnal Pengurusan, 36, 59-68 
Muhammad. (2005). Bank Syariah Problem dan Prospek Perkembangan di Indonesia. Yogyakarta: Graha Ilmu.

Natalia, E., Dzulkirom, M, \& Rahayu S.M. (2014). Pengaruh Tingkat Bagi Hasil Deposito Bank Syariah dan Suku Bunga Deposito Bank Umum terhadap Jumlah Simpanan Deposito Mudharabah (Studi pada PT. Bank Syariah Mandiri 2009-2012). Jurnal Administrasi Bisnis. 9(1), 1-7

Perwataatmajaya, K.A. \& Tanjung, H. (2007). Bank Syariah (Teori, Praktik, dan Peranannya. Jakarta: Celestial Publishing.

Rivai, V. \& Arifin. A. (2010). Islamic Banking Sebuah Teori, Konsep, dan Aplikasi. Jakarta: PT Bumi Aksara.

Sudarsono, H (2009). Dampak Krisis Keuangan Global terhadap Perbankan di Indonesia: Perbandingan antara Bank Konvensional dan Bank Syariah. La Riba Jurnal Ekonomi Islam, 3(1), 12-23

Widarjono, A. (2013). Ekonometrika Pengantar dan Aplikasinya. Yogyakarta: UPP STIM YKPN. 